\title{
Citizenship Discourses: Production and Curriculum
}

\author{
Maria Olson, Andreas Fejes, Magnus Dahlstedt and Katherine Nicoll
}

\section{Linköping University Post Print}

\section{Tweet}

N.B.: When citing this work, cite the original article.

This is an electronic version of an article published in:

Maria Olson, Andreas Fejes, Magnus Dahlstedt and Katherine Nicoll, Citizenship Discourses:

Production and Curriculum, 2014, British Journal of Sociology of Education.

British Journal of Sociology of Education is available online at informaworldTM:

http://dx.doi.org/10.1080/01425692.2014.883917

Copyright: Taylor \& Francis (Routledge): SSH Titles http://www.routledge.com/

Postprint available at: Linköping University Electronic Press http://urn.kb.se/resolve?urn=urn:nbn:se:liu:diva-105474 


\title{
Citizenship discourses: production and curriculum
}

Maria Olson(a), Andreas Fejes(b), Magnus Dahlstedt(b), Katherine Nicoll(c)

a) Stockholm University, Sweden

b) Linköping University, Sweden

c) University of Stirling, Sctoland, UK

Contact: andreas.fejes@liu.se

\section{Published in British Journal of Sociology of Education ahead of print 2014 DOI: 10.1080/01425692.2014.883917}

\begin{abstract}
This paper explores citizenship discourses empirically through upper secondary school student's understandings, as these emerge in and through their everyday experiences. Drawing on a post-structuralist theorisation inspired by the work of Michel Foucault, a discourse analysis of data from interviews with students is carried out. This analysis characterises three discourses of the active citizen - a knowledgeable citizen, a responsive and holistic citizen and a self-responsible "free" citizen. The analysis raises questions over the implications of contemporary efforts for the intensification of standardising forces through citizenship education. It also stresses the notion that engaging students actively does always also involve discourses other than those stressed through the curriculum, which nurtures the body and nerve of democracy itself.
\end{abstract}

Key words: citizenship education, citizenship discourses, curriculum, citizenship, Foucault, condition of possibility

\section{Introduction}

The question of citizenship has been on the agenda of politicians, policy makers and civic organisations over the past decades in the field of education and more widely (Isin \& Wood, 1999). Traditionally, the concept of citizenship referred to a relation between the individual and the state, guaranteeing citizens the legal status as full members of society with certain rights and obligations (c.f. Marshall, 1950). More recently, the notion of citizenship has come to focus not only on the legal dimensions of citizenship but also on those that are social and cultural (Isin \& Turner, 2002; Lister, 2005). Citizenship is no longer conceived only in terms of a legal relation between the individual and the state, but more often as a 'total relationship, inflected by identity, social positioning, cultural assumptions, institutional practices and sense of belonging' (Werbner \& Yuval-Davis, 1999, p. 4). Correspondingly, educating for citizenship not only concerns the development of formal knowledge of rights and duties, but also identity formation that covers political, cultural, economic and working life (Birzea, 2005).

In established democracies the concern for a revitalisation of citizenship education has often been fuelled by decreasing levels of civic participation and political involvement. Social fragmentation and exclusion are seen to be related to these decreases (cf. Hedke \& Zimenkova, 2012). The active participation and involvement of citizens in political and social citizenship practices is also seen as important for the legitimacy of democratic governance, as this is considered to crucially depend on the extent to which democratic structures and practices are supported and 'owned' by citizens. The idea of 'active citizenship' has thus become central, for example in the European Union's policy approach to the development of citizenship and educational formation for citizenship (Olson, 2012a). In addition, 'active citizenship' is a vital concern in Sweden as an educational context (Dahlstedt, 2009). Even 
though Swedish education does not contain a formal and delimited subject matter called citizenship or civic education, its concern for the formation of students for active citizenship is expressed implicitly in education policy and practice (Carlbaum, 2012; Irisdotter Aldenmyr, Jepson Wigg \& Olson, 2012). It also has historically settled references (Englund, 2005), which is manifested today through explicit emphasis in the curriculum for pre-school, compulsory, upper secondary school and adult education (c.f. National Swedish Agency for Education, 2011 [NSAE]).[1]

To date, few discursive approaches to the empirical exploration of active citizenship have been engaged. Our point of departure is a post-structuralist theorisation that draws on some resources from the work of Michel Foucault (1972, 2007). It explores citizenship discourses through student's understandings of their activities as these emerge in and through their everyday experiences. Taking a discursive approach and asking research questions that focus on students' understandings of citizenship activity we hope to open up the research terrain for alternative insights in understandings of citizenship and its relationship to education and the educational subjects involved in the curriculum. We have wanted to explore whether we would be able, through this kind of elicitation of description and discourse analysis, to set out markers where the possibilities and limits to citizen education discourses might emerge as issues to be confronted, recast and re-evaluated. With the premise that citizenship is articulated by citizens (Lawy \& Biesta 2006; Olson, 2012b) we want to see what might be possible to 'render visible' (Klee, in Rabinow \& Rose, 2003, p. 3) by talking with students and exploring their descriptions as discourse.

The paper reports on a study carried out with a small number of students in Sweden. The study identified and explored the citizenship discourses constituted and activities identified by those students. Our research questions in this study, with regard to the students selected, were: what characterises students' descriptions of citizenship activity? And, what discursive and non-discursive conditions of possibility may support these descriptions? Our aim is to produce a partial and exploratory account. This is not generalizable in its findings, but a provisional and specific description of citizenship as it emerges through the statements of these young students in Swedish upper secondary school.

\section{Research on citizenship in education}

There is an ongoing discussion in educational policy, research and practice about the contribution of education to citizenship. These emanate from different disciplines and focus on questions about the shape and form of education for democratic citizenship from a variety of positions. A substantial body of this work deals with theoretically and philosophically entangled questions about the configuration of citizenship through education in democratic societies (c.f. Biesta, 2011; Callan, 1997; Peters, Blee \& Britton, 2008; Westheimer \& Kahne, 2004). Some of this research emerges from political theory. This tends to stress citizenship and education in juridical terms, and in terms of a vertical or top down relationship between the individual and the state (cf. Feinberg \& McDonough, 2003; Kymlicka \& Norman, 2000). Other approaches focus relationally and horizontally, on institutional and interpersonal aspects of citizenship and education. Citizenship in this latter group is quite dominantly depicted as situated in concrete practices and constituted by individuals and groups in their daily living (Lister, 2005; Osler \& Starkey, 2005). A growing body of empirical research consists of a mixture focusing on these two dimensions. Some of this assesses the impact of educational processes and practices on the knowledge, skills, values and dispositions necessary for good citizenship (c.f. Davies, 2010; Keating, Benton \& Kerr, 2011). 
What characterises much of this work is a focus on the role of education in the preparation of individuals for citizenship. Although recognising people as citizens is emphasised for instance in the UK and Swedish education policy (c.f. LTS, 2002; NSAE, 2010), citizenship practice is still predominantly considered to be the outcome of particular educational trajectories (Biesta, 2011). This strong focus on what is not (yet) attained by the students fails to make productive connections with what already is, which indicates that existing activities of young people as citizens appear to be relatively unexplored (Olson, 2012c). Although there has been some research asking students for their opinions about citizenship, where students' 'voice' on citizenship is taken into serious account (see France, 1996; Hall et al., 1999) and some exploration of the citizenship activity of young people (see LTS, 2002; Weller, 2007; Wilson, 2000), there appears to be few discursive and empirical explorations of such understandings.

\section{Theorisation - a point of departure}

Policy and citizenship curriculum commonly position citizenship education as a preparation for life in abstract, generalised and predefined forms and positions students as 'needing' specific knowledge, values and competencies for citizenship - as being at the outskirts or margin of the community of citizens who act (Olson, 2012a, 2012b). Rather than starting off from statements that are stressed in policy and the curriculum, our discursive approach focuses on upper secondary students' own understandings and activities of citizenship when asked about it, even though these points of departure intermingle in that the upper secondary curricula as well as the teaching situation often involves students' understandings, activities and experiences of citizenship.

A discursive approach is important for us in that it allows us to explore discourses and their processes of production and how they emerge and are supported. Student citizens do not act in a void, but draw on wider discourses and social and institutional provisions and material resources for them (Elm-Larsen, 2006; Nicoll et al., 2013; Olson, 2012c). There is an argument to be had that by incorporating wider understandings of citizenship into the curriculum it might be possible to capture the imagination and motivation of young people in education by drawing on their current engagement and interest (Biesta, Lawy \& Kelly, 2009; Lawy \& Biesta, 2006; Öhrn, Lundahl \& Beach, 2011). However, for a discursive approach such as the one that we deploy there is a normative difficulty in making any such suggestion for incorporation. Pedagogies are bound up within relations of power that are politically sanctioned and predefined, and there is potential danger in such normalisation processes that we discuss later.

The research approach is post-structuralist and discursive. In this approach 'discourse' includes what is said through speech or writing, but is more than this. A discourse is not just the signs of language, but a system for the formation of a group of statements that is not delimited to what is being said (Foucault, 1972). In relation to citizenship, discourses are constituted through statements of citizenship that emerge as possibilities at a particular time and location. These statements are considered as entities that allow signs to assign specific and repeatable relations to objects, subjects and other statements.

The current and explicit emphasis on citizenship within policy and curriculum suggests an increasing governmentalisation of the state (Foucault, 2007). However, 'government' is not only concerned with governing through law-making, policy decisions and institutional curriculum practices and so forth, but occurs in and through discourses and practices which inform actions and are drawn on in our relations to ourselves (Fejes \& Nicoll, 2008). Foucault 
(2007) uses the concept of the 'conduct of conduct' to analyse how people are constituted as governors of others and the self. Governmentality is the repetitions 'imminent' to this relationship, 'whatever the level of analysis being considered (parent-child relation, individual-public power, population-medicine, and so on' (Senellart, 2007, p. 389). Governing then is the guidance of conduct, where behaviour attempts to shape the field of possible action in relation to these repetitions. This makes it possible to approach citizenship as something other than that which only implies citizenship as a question of government of the State, i.e. by policy and curriculum. It allows for the involvement of policy or curriculum to be but one element in a wider discursive network that shapes young students' citizen discourses in education and elsewhere.

The approach makes it possible to show the complexity of citizenship: the citizen promoted through policy the institution and curriculum is not only promoted as a solution to a political problem or juridical, political or geographical entity, but is a strategy of government aimed at shaping desirable outcomes as regards citizenship (c.f. Cruikshank, 1999). Processes and strategies of government operate also through the relations formed through the media, family, social groups and networks etc. These 'matrices of affinity' appear natural although they are also discursive productions, or constructions (Rose, 1999, p. 177). This approach then allows for open-ended questions about what constitutes 'the citizen'.

We have adopted, lightly, a notion of 'conditions of possibility'. This emerges in Foucault's writing as those conditions supporting the possibility of the existence of discourses that are relatively accidental (c.f. Foucault, 1970, xi). We use this idea for student interviews and subsequent analysis to see what the students say and what the analysis points to. We explore then what the idea might 'render visible' (Klee, in Rabinow \& Rose, 2003, p. 3) for an analysis of citizenship discourses that does not exclusively involve the curriculum.

\section{Studying citizenship discourses}

To explore discourses and activities we elicit upper secondary students' descriptions of citizenship and citizenship activities. By selecting students preparing for higher education in their last year of study in upper secondary school, we hope to engage those who have quite settled ways of being, acting and thinking. Six students (four young women and two men, 1819 years) engaged in the social science program were selected. They had engaged in the Swedish curriculum through their schooling (i.e. from age 6 to age 19). In Sweden there is no subject called 'citizenship education' or 'civic education', instead democratic citizenship is embedded in subjects as the responsibility of the school (NSAE, 2011). Previous research (c.f. Bronäs, 2000; Öhrn et al., 2011) shows that it is mainly Social Science that takes this responsibility.

Students were invited to document their citizenship activities with a pen-camera over seven days. We explained that we wanted them to define citizenship themselves; taking photographs, audio or video recording examples of citizenship activity.

Each student was interviewed and encouraged to share their filming experiences. The focus was not on how they came to conceptualise, act upon, depict or explicitly connect with the concept of citizenship, but on what they felt was hard, embarrassing, difficult, dubious or easy in the documentations and why this was the case. The elicited descriptions were not measured against any pre-defined or idealised notion of citizenship that we might have imposed.[2] 
In the analysis we looked for key themes and regularities. The participants' descriptions of their documentation involved several themes; home, everyday activities at a local level, to be helpful and care, belong and adapt, read the newspaper, pay the bills, exercise one's freedom in manifold ways, create and experience rituals of life, as some examples. Our focus was on characterising statements in terms of regularities, subjectivities produced through these, the reasoning involved, and what made a particular description possible and constrained it. Attention was directed at recurrent concepts, meanings, relationships formed through regularities both within and between descriptions. We saw these as being constitutive of the objects that they describe (c.f. Foucault, 1980; Fejes, 2011).

The analysis was not only concerned with what students say that they do as citizens, but also with the conditions of possibility through which they came to say what they do, i.e. the discursive constellation through which attempts at citizen activities and citizenship production are made, and the discursive possibilities and limits to this. Conditions of possibility might be both discursive and extra discursive (Foucault, 1972). The former are those rules needed in order for certain statements and discourses to emerge, and the latter are those material conditions that make citizenship activities possible. In relation to this study, extra discursive conditions are those that emerge through statements about what is materially supportive for an activity. It might be the need of a ballot paper or ID documentation in order to cast a vote in the election, or it might be the availability of a certain 'space' in order to paint graffiti etc.

\section{Citizenship characterisations}

Three interrelated characterisations of discourses of the citizen emerged from the analysis - a knowledgeable, responsive and holistic, and self-responsible and "free" citizen. While the first and the second were strongly related to duty and obligation, the last was related to rights and freedom of will.

\section{The knowledgeable citizen}

What we have characterised as a knowledgeable citizen emerged through analysis of statements from interviews held with Linda, Evy and Sandra. Citizenship here was linked to a notion of responsibility for knowledge seeking, for gaining knowledge and awareness, and in taking a stand for things that happen in the world. According to this particular understanding, citizen activities could be: to pay bills, read the newspaper, know how the society in which we live and work is organised or functions, be updated on what happens in society, have an opinion on certain issues, make and take a stand, be able to influence, and know how to influence and navigate in society at societal, political or local levels.

Regularities in and between the statements from Linda, Sandra and Evy were identified. In the interview with Linda, the description of the knowledgeable citizen was connected to positive characteristics that she herself holds. In the interview, to engage in knowledge is to enact your citizenship - to come into being as a citizen. For instance, she emphasised the need to "feel that you are part of... to contribute to society by your own action-taking and that you in some way want to continuously improve society". To be a citizen means through this description, to nurture and hold: (1) a feeling of belongingness to a specific community; (2) a will to improve society, and (3) action in contribution to society. This description focuses on the individual's belonging and obligations to the wider societal community. In the interview with Sandra, regularities of detail supported this general description of citizenship. However, knowledge and awareness of how political things are in society were stressed indirectly, but in a negative way. She described herself in terms of not knowing and not being able to discuss and make an argument or statement about these things, as her classmates do. The main reason given for 
this, was that her parents do not talk about such issues at home. Sandra stressed that she feels somewhat outside the ongoing talk about political issues of her peers both in and outside school, as a result of a lack of training in such engagement within the home.

A knowledgeable citizen was also constituted in the interview description from Evy. Her reasoning was quite similar to Linda's. Regularities in what was said from Evy's interview, as Linda's, stress knowledge and awareness as vital to citizenship. References to this were made in a positive way - Evy both knows and is aware of matters necessary for fulfilling the obligations of a good citizen. However, instead of almost entirely connecting (individual) knowledge and awareness to society at large, as is the case with the descriptions from the interviews with Linda and Sandra, she also connects these (self) characteristics to a local everyday level.

A macro level was also constituted through the interviews where the knowledgeable citizen is described in terms of a knowing society - what it looks like, knowing about technical stuff, "technical machines", like the Internet, so as to exploit certain opportunities; getting to know people, paying bills, engaging with news. Here, Evy specifically referred to the situation of "today", i.e. the importance of knowing about the Internet, which makes knowledge important in exercising one's rights as a citizen. However, the importance of knowing about the Internet and other technical 'stuff', also emerges in a negative way in the interview with Evy, particularly in relation to specific groups. According to Evy, old people are often excluded, as they do not have the same access to take up their citizen rights as younger people: "kind of, okay, but if you don't have Internet, what do you do then?" Another negative framing - the not-knowing of a specific group - was that of 'down-and-outs'. Talking about down-and-outs, Evy states that "the question is whether they know, really, their rights, or kind of..." Another group of not-knowing beings are animals. Evy describes these as being innocent. "Humans have kind of a natural capacity of thought, to be able to think, but these animals, they don't know what to do and they are so innocent".

The locus for the knowledge in Evy's interview is at the local level. Her talk centers on knowledge about the (local) community in terms of the opportunity to move around without fear and without feeling restricted - this is talk about moving in geographic space. The knowledgeable citizen has knowledge about everything that one can do as a citizen on a daily basis; going to a shop, knowing where to head for a walk or run, what roads to take, what it looks like in the local community, to be able to orient oneself, and know what one can do.

There are several kinds of supports to citizenship identified in Linda's, Sandra's and Evy's descriptions. These implicate discursive support for the constitution of the 'figure' of the knowledgeable citizen. One of these is the presence of a certain body of knowledge through which it becomes possible to become active and engaged. In the interview statements we can see how an important site for the availability for such knowledge is the home - to be in a home were political issues are openly articulated and discussed. As mentioned before, when Evy speaks about knowledge, she mentions her parents at home. She says that her home background helps her a lot in school.

Even though they might have very limited knowledge about something, they are anyhow... if one is initiated in news and so on one has some thoughts about everything and then one can... and then one can be helped very much by that [in school], that's the way it is... 
Lack of such circumstances is identified by Evy as a hindrance to becoming a knowledgeable citizen. Another site for the gaining of knowledge emerging from the interviews is the school - to be able to be part of discussions about (mainly) political issues. In and through school, knowledge becomes available mainly through peer discussion in the classroom.

\section{The responsive, holistic citizen}

A responsive and holistic citizen emerged through regularities in statements in the interviews with Sandra, Oliver and Marina. This kind of citizen is characterised as someone who acts for the benefit of the wider society, or even the world. Being a citizen in this sense is a feeling of belonging to something greater, taking responsibility for different modes of life and death. This rationality of citizenship is holistic, where polarities such as life/death, growth/decay, happiness/sadness emerge in the interview transcripts.

In the interview with Sandra, citizenship is framed, first, as a collective phenomenon that stands in a tension-filled relation to her own and other people's private lives, and, second, as something that has to do with taking action. As concerns the first, citizenship is collective, it refers to a will to sacrifice; a sacrifice that is done for "something more", "something bigger" than just doing something for oneself. Sandra mentions her hobby, horse riding, as something that may not be considered as an act of citizenship as it is not collective in any respect: "not even a team is involved, like in football, it's just a hobby". As regards the second framing, Sandra stresses, "If you just exist, you are not a citizen". If you just let live, it is not a citizenship activity. According to Sandra you have to engage in order to change, to provide for growth. Furthermore, citizenship is repeatedly depicted in terms of concrete action taking - "helping", or "to help". This activity of helping is something that goes beyond one's private life and interests, and is related to - which is partly opposed to what she says about knowledge - one's knowledge about the world.

This collectively oriented activity of helping can be seen as holistic in that it is related not only to other human or non-human beings but also to the environment. It is a kind of helping activity that involves interaction with different materials; for example, "helping to empty the dishwashing machine at home", or "going with the subway". It can also be a matter of engaging in other people's lives (known people, or better not known), in order to make life better for them. For instance, Sandra mentions the activity of voting, which is an action taking that is framed as located at the margin of the helping activity. On the one hand it is a formal action-taking, requiring some level of knowledge (see the discussion about the knowledgeable citizen), not directed toward any concrete other or cause, on the other it tends to be collectively oriented (one votes to help provide for a better world in the future).

In the interview with Oliver life, death and holistic notions of growth are also evident. Life comes emerges as a central concern, related to a multitude of things and organic matter. Care taking, belonging and growth, are here central themes related to being part of life and the world. There is a dutiful, ethical aspect involved in this notion of citizenship. To be a good citizen means making a difference in the world. To make a difference could be about doing the dishes at home without being asked to do it (when it's the girlfriend's turn), to plant and give water to plants, let music into life, and let life grow by giving birth to children and taking care of them. These are some examples of the holistic citizenship activities described by Oliver.

Turning to the interview with Marina, joy, death and creativity are described as important and related to citizenship activities. Her description, as is the case with Oliver, centers on life 
itself. She mentions creating small pieces of art as crucial citizen activities - spreading joy in life:

a tile of pearls that someone has done and hung on the wall [in school], and that portrays a man that says 'hi' like this, happy, a smiling man... and then heart as well... it's a nice thing and it is kind of a gesture to give joy to other people... and to express something in that person that... wants to pull forth and then I thought... why not.

In the interview with Marina citizenship is also construed as a matter of feeling part of a bigger community, without being "outside" it; to feel at home, descending, flow and existence as something that is linked to citizenship as experience. Social aspects are here identified as important. When talking about citizenship activities Marina mentions the funeral of her grandfather; "that people are citizens there as well, and that it is also part of kind of everything, and that people are sad too, not only taking pictures of joyful things". To be on one's way, toward a goal, to accept what is;

small things, one should look deeper into them....all of us are citizens even though we don't feel that this is the case...citizenship, isn't it a feeling kind of, it is what I think, it has to do with a feeling. Am I, do I feel part of the whole? Then I am a citizen.

Security and belonging are other words that are repeated in the interview with Marina. She also stresses music as a kind of ("leftish" political) belonging that is part of her selfactualisation and self-expression in life.

A condition of possibility for the experience of a responsive holistic citizen emerging in the interviews with Sandra, Oliver and Marina may be an aesthetic responsiveness; aesthetic expressiveness or aesthetic experience. This dutiful responsiveness helps bridge the polarities life-death, growth-decay and joy-sadness within a holistic notion of citizenship where experience and expressiveness emerge as vital and dutiful citizen responsibilities. Three different sites of availability of such an aesthetic responsiveness come about in the interviews: art, music and growth. These stand out as nodes of experience that help or make life better by providing for social, societal, biological growth - in human and non-human, environmental registers. These sites - art, music and growth - come to be vital in this responsive holistic citizenship in that they call for symbolical action taking. To take part in certain activities that are more or less ritualised, such as funerals, creative aesthetic artistic processes, music and the joy of life or growth itself, seem to be constituted as citizenship through these discursive activities. Put differently, these sites and their related action taking could be seen as a transitional space where life comes into question as civic life in and through aesthetic registers. Expressing and experiencing life aesthetically, through art, music and growth become bridging necessities - a condition of possibility - for a responsive holistic citizenship.

\section{The self-responsible "free" citizen}

Last, a self-responsible "free" citizen emerged in the interviews with Stephan and Evy. Here freedom and self-independence were regularities of description. A citizen figure emerges who should be able to do what she/he wants. A citizen who should decide about her/his own life, and who uses the space provided by structures, rules and regulations in the society in which she/he lives to actualise wishes and visions for future life courses.

Turning to the interview with Stephan, acts of citizenship were a matter of 
going to the gym...to sleep at a friend's place for days...to go to the supermarket and buy whatever I want...to be able to go by bus...to have access to a physiotherapist in order to heal my wounded knee...that I have the opportunity to take responsibility for my own life.

Freedom was a concept repeated in Stephan's descriptions, as well as "I". In the interview with Evy, freedom and independence are also stressed in terms of going to the gym and the store nearby. They are also described in terms of rights and decision-making over one's own life: "to have access to things", "to orient oneself", "to navigate" on one's own (as a citizen, the right to use and take advantage of one's civic freedom, as a sign of independence). In the interview with Evy, freedom was described as "to be able to feel safe and secure, i.e. to go out for a jog for safety reasons", to be able to go and buy things somewhere nearby, "to manage one's own life".

Freedom was talked about as a specific condition of possibility for the citizen. In the interviews with Stephan and Evy, the enactment of freedom was described as made possible through institutional rules, laws and regulations. Freedom is positioned as a pre-requisite for citizenship, and regulation is positioned as providing the space for freedom to operate. To be able to speak about freedom in this way, a non-freedom appears to be necessary. Here Stephen, for example, identifies other countries as not allowing freedom to operate, at an individual or collective basis. In this way freedom - in positive, affirmative terms - is related to a particular cultural sphere of which Stephan says he is part.

That it is cool to live in such a country [considering the freedom provided in this country], but if I had lived in... North Korea or Saudi Arabia or Afghanistan I might not have had it [the same amount of freedom].

Freedom was also raised by Evy, where she stresses travelling abroad as an activity linked to citizen freedom. She talks about freedom thus in a somewhat different way. The freedom involved in travelling here has to do with laws and regulation. Interestingly, it is at the same time a freedom from (Swedish) cultural norms, which Evy says are sometimes quite unsettling and distressful, and narrows the space for freedom. Like Stephan, Evy related the freedom to travel to a positive affirmative notion of cultural freedom; one where Sweden - as a legislative and juridical, geographical and cultural space - allows for freedom.

However, a third condition of possibility appears from Evy. While she described Sweden as a place for freedom to move, she also stresses a non-freedom in the "Swedish culture". She considers Swedish culture to narrow her freedom in that it involves a set of normative "taboos" for what is allowed or "ok" to do, or not to do, ethically and socially. Evy's negative notion of freedom, where Sweden as cultural place and space is described as imprisoning or at least narrowing freedom, emerges in terms of travelling. The escaping of the normatively narrowing cultural locus or space of Sweden seems to be made possible by travelling to other geographical locations, to 'other cultures'. At the same time the freedom to travel, to move, refers to a positive notion of freedom that comes into being at a site of legislation and law. Hence, Evy's twofold and intimately entwined construction of freedom as the 'ability-tomove' and the 'traveling-away-from', which emerges at a site of law and regulation, becomes even more intricate. Paradoxically, she relates freedom to specific Swedish cultural values by saying that freedom is "to share one's own values from home with other people". 
Taken together, the self-responsible, 'free' citizen characterised from Stephan's and Evy's interview descriptions is shaped with a partial absence of normative regulations and taboos (in the society in which one lives). This absence is positioned as a condition of possibility for freedom to operate. Freedom is also produced in the presence of regulation (jurisdictive ones). Thus, an absence and presence of regulation are positioned as working together as conditions of possibility for the operation of freedom. And geographical self-mobility appears significant in producing the regularities for this self-responsible, 'free' citizen.

\section{Citizen production and the curriculum}

We have characterised some forms of citizenship possible and intelligible today, articulating quite specific ways of thinking and acting. We have wanted in a pragmatic way to see what students say and consider what these might 'render visible' of citizenship; what might emerge as alternative insights or understandings of active citizenship. We tentatively suggest that these characterisations differ and have similarities with those promoted within the Swedish curriculum - with its commissioned assignment to provide for an active democratic citizenry by teaching about citizenship, providing opportunities to exercise citizenship in school, and organising school in a way that offers opportunities to experience (democratic) citizenship (cf. Öhrn et al., 2011). Thus, we have shown the 'invention' of people when they draw on modes of thought and activities from disparate locations within discourses in the constitution of the citizen-self.

What comes into question in these drawings, as concerns citizenship and its relationship to education? The characterised knowledgeable citizen is active in gathering knowledge of understanding about and improvement of society, directed at local or wider social or political understanding. Conditions of possibility for knowledge and to engage in exercising rights, were skills in the use of technology, and knowledge of rights and of the local community. Engagement as a knowledgeable citizen was understood as supported through family discussion and discussion in the school. From knowledge the capacity of citizens to exploit opportunities for active engagement was seen to emerge. Here governmentality operates through knowledge and the citizen seeks to inform his or herself in order to know how to act, and in discussion with school and family formulates his or her responses to issues.

A responsive and holistic citizen emerged through helping activity; going beyond private life and interests. Helping was actively contributing to a collective dimension (including the nonhuman) by interacting with things, for collective benefit. This form of citizenship was described as one of ethical direction and aesthetic contribution. Engaging with others in sadness and joy, feeling safe and belonging to a whole was a form of living. A condition of possibility emerges as an ethical focus on collective benefit and aesthetic responsiveness. This is being depicted in terms of ties with family, people and animals, in engaging with doing things materially to help others, voting to provide for the world for the future, and engaging with an ethics and aesthetics of care and responsiveness for life and living. Here there begins to unfold a view of the citizen-self as constituted through discourses oriented strongly to others through an ethics, aesthetics of experience and care of others as a way of existing, of living.

The self-responsible "free" citizen characterised is one for whom the freedom for selfdetermination and responsibility, and a collective freedom within a governed and safe society, come into question as conditions of possibility. Swedish cultural norms were considered to be potentially constraining, but rule, law and jurisdictive regulation produced the space for the freedom needed to enact active citizenship. The freedom for movement or mobility was 
understood as produced through regulation. Put briefly, in this citizenship understanding freedom emerges as a pre-requisite for citizenship; it is a freedom shaped by cultural norms, laws and taboos, and at the same time also regulated and constrained through them. The conditions of possibility for freedom to act, mobility and visions for future life courses are being stressed in terms of both the absence and presence of regulation. This makes this condition of possibility a complex and to some extent contradictory one. Travelling tends to nurture this complexity.

Through this kind of elicitation of description and discourse analysis we have wanted to explore whether we could be able to set out markers where the possibilities and limits to citizen education activities might emerge as issues to be confronted, recast and re-evaluated. Rather than aiming at a critique of education policy or the Swedish curriculum for citizenship in upper secondary school we have aimed to open up a space for different ways to think and act with regard to citizenship teaching and learning. Our analysis has examined young people's action taking and sense making through and around the citizenship discourses. These processes can be considered to be partly located beyond those of the curriculum for citizenship. We may thus consider the citizenship curriculum to be productive (not least in its threefold depiction of democracy and citizenship learning that comes to the fore in the curriculum) but also potentially limiting. One way to critically interrogate but also to open up space for different ways for approaching citizenship education, would be to attempt to incorporate students' understandings of their citizenship into the curriculum to a greater extent than might be the case, which would be to make these understandings available to normalisation, standardisation and regulation. We argue this to be problematic in that it would support an idea that the 'real' world can be directly presented through the curriculum. Or that citizenship can or should be standardised, measured to its full, or universalised, in a world of plurality.

Understandings of citizenship emerge from many places. For young people they are undoubtedly partially formed through their experiences of schooling. However, they are continually being adjusted, as influenced from the repetition of views within the media, at home, through the Web, social ties, and more widely in their everyday living. Understandings elsewhere act in the normalisation of particular views of the self as citizen, as these are repeated, taken up with regularity, within students' articulations of themselves. Rather than evaluating or judging these understandings one way or the other in relation to the educational assignment we have highlighted circumstances where, for example, the WWW, family and school are understood equally as sites where citizenship is formed.

This does not mean that the ongoing constitution of citizenship that takes place in other sites than in education are more vital, vivid or 'authentic'. Neither does it mean that some regularities, modes or sites of citizenship are more valuable or refined than others. What it denotes, we argue, is an educational responsiveness to the 'fact' that there is a limit to what can - and perhaps should - come into question as citizenship in the realm of education. At the same time this responsiveness involves the 'fact' that citizenship production in sites other than education is to certain extent always already part of a curriculum. This does not mean that there are openings in the classroom for actualising upper secondary students' citizenship production which takes place in sites other than those of education: this production does not lend itself to any form or formula estranged from its discursive conditions of possibility (it simply does not, and cannot, be subject for calculation, didactic design or methodological control). But it means that the constitution of citizenship being actualised in different educational subject bodies, traditions and teachers' translations of curriculum is already, by 
necessity, part of the educational assignment of young people's citizenship learning. Put differently, this citizenship production is always already part of 'curriculum making' that transcends any predefined and fixed educational 'curriculum delivery'.

\section{Outlook}

If we consider the ongoing processes of citizen self-making in the young upper secondary school students' action and thinking of citizenship, the citizen-agent that is given rise to and formed in part through the curriculum, 'cobbled together' with ideas and repetitions of understandings and practices from elsewhere, can be considered at each moment, as part of the fragmentary 'outcome' of intersecting processes of normalisation and government.

In trying to include or shape people more or 'better' through the curriculum, we may fail to recognise that citizenship is always already shaped in part elsewhere. Citizens are formed even where young people are not students. The heart of the hazard involved in standardising school discourses where students are considered to be not-yets in relation to the alleged outcome of curriculum in Sweden and elsewhere (Olson, 2009, 2012a, 2012b), is perhaps thinking that citizenship education can overcome the difficulties identified. What should not be forgotten is that citizenship education in school is always, by necessity, cobbled together with the ideas and repetitions of view and practices from elsewhere, and that it is the very blend that brings the citizenship curriculum into being and into question in school as elsewhere. To put it differently, it is the notion that citizenship production - by necessity - is blended and in constant making, wherever it takes place that nurtures the promise of citizenship in the first place. Furthermore, this notion serves as to assure the very nerve and body of democracy itself - in education in general, and in citizenship education in particular as it increases expression and 'ownership' of democratic structures and practices.

\section{Notes}

1. A central assignment in the Swedish educational curricula is to provide for an active democratic citizenry by teaching about democratic citizenship, providing opportunities to exercise democratic citizenship in school through the exertion of student influence, and organising school in a way that offers opportunities to students to experience democratic citizenship (Öhrn et al., 2011).

2. Examples of the main questions asked; what did you find hardest/easiest with this task? Why was that? Did you erase any documentation (photo, film or sound recording)? Why/why not? As evident, the photos, audio and video recordings made by the students by means of the pen-camera were the only resources used for the interviews. The interviews were therefore unstructured. An important circumstance here was that that not all kinds of citizenship activities were - or even could be - part of their documentation. To mention one such category; voting and other such formalised citizenship activities were not likely to be documented, as it was not an electoral time in Sweden.

\section{References}

Biesta, G. J. J. (2011) Learning democracy in school and Society: Education, learning and the politics of citizenship (Rotterdam, Sense Publishers).

Biesta, G. J. J., Lawy, R. \& Kelly N. (2009) Understanding young people's citizenship learning in everyday life: The role of contexts, relationships and dispositions, Education, Citizenship and Social Justice, 4(1), 5-24.

Birzea, C. (2005) European citizenship as a cultural and political construct, Journal of Social Science Education, 3. Available online at: http://www.jsse.org/2005/2005-3/birzeaeuropean-citizenship-as-a-cultural-and-political-construct (accessed 15 August 2012)

Bronäs, A. (2000) Demokratins ansikte: en jämförande studie av demokratibilder i svenska och tyska samhällskunskapsböcker för gymnasiet. Stockholm: HLS förlag.

Callan, E. (1997) Creating citizens. (Oxford, Oxford University Press). 
Carlbaum, S. (2012) Blir du anställningsbar lillela vän?: Diskursiva konstruktioner av framtida medborgare $i$ gymnasiereformer 1971-2011. Diss. (Umeå, Umeå University Press).

Cruikshank, B. (1999) The will to empower: Democratic citizens and other subjects (New York, Cornell University Press).

Dahlstedt, M. (2009) Aktiveringens politik: Demokrati och medborgarskap $i$ ett nytt millennium (Malmö: Liber).

Davies, L. (2010) Citizenship, Education and Contradiction, British Journal of Sociology of Education, 22(2), 299-308.

Elm-Larsen, J. (2006) Governing the spaces on the margins of society, in: G. Marston \& C. McDonald (Eds) Analysing social policy: A governmental approach (Cheltenham, Edward Elgar).

Englund, T. (2005) Läroplanens och skolkunskapens politiska dimension: Olika utbildningskonceptioner med speciell hänsyn till medborgerlig och politisk bildning (Lund, Studentlitteratur).

Feinberg, W. \& McDonough, K. (2003) Citizenship and Education in Liberal-Democratic Societies: Teaching for Cosmopolitan Values and Collective Identities (Oxford, Oxford University Press).

Fejes, A. (2011) Confession, in-service training and reflective practices, British Educational Research Journal, 37(5), 797-812.

Fejes, A. \& Nicoll, K. (Eds) (2008) Foucault and Lifelong Learning: Governing the Subject (London, Routledge).

Foucault, M. (1970) The order of things: an archaeology of the human sciences (London, Routledge).

Foucault, M. (1972) The archaeology of knowledge (New York, Harper).

Foucault, M. (1980) Michel Foucault: Power/knowledge, selected interviews and other writings 1972-1977 (Brighton, Harvester Press).

Foucault, M. (2007) The politics of truth (Los Angeles, Semiotext(e)).

France, A. (1996) Youth and citizenship in the 1990s, Youth and Policy, 43, 28-43.

Hall, T., Coffey, A. \& Williamson, H. (1999) Self, space and place: youth identities and citizenship, British Journal of Sociology of Education 20(4), 502-513.

Hedke, R. \& Zimenkova, T. (Eds) (2012) Education for Civic and Political Participation. A critical approach (London, Routledge).

Irisdotter Aldenmyr, S., Jepson Wigg, U. \& Olson, M. (2012) Worries and possibilities in active citizenship: Three Swedish Educational Contexts. Education, Citizenship and Social Justice 7(3), 255-270.

Isin, E. F. \& Turner, B. (Eds) (2002) Handbook of citizenship studies (London, Sage).

Isin, E.F. \& Wood, P. K. (1999) Citizenship and identity (London, Sage).

Keating, A., Benton, T. \& Kerr, D. (2011) Tracing the trends and transitions in young people's citizenship practices: what are the implications for researching citizenship and citizenship education? Educational Research, 53(2), 223-235.

Kymlicka, W., \& Norman, W. (2000) Citizenship in diverse societies (Oxford, Oxford University Press).

Lawy R. \& Biesta G. J. J. (2006) Citizenship as practice: The educational implications of an inclusive and relational understanding of citizenship. British Journal of Educational Studies 54(1), 34-50.

Lister, R. (2005) Young people talking about citizenship in Britain, in: N. Kabeer (Ed) Inclusive citizenship (London, Zed Books).

LTS (Learning and Teaching Scotland) (2002) Education for citizenship in Scotland: A paper for discussion and development [online]. Advisory Council of Learning and Teaching 
Scotland (Dundee: Learning and Teaching Scotland). Available online at: http://www.ltscotland.org.uk/citizenship/managementtoolkit/planning/paper/index.asp (accessed 26 August 2009)

Marshall, T. H. (1950) Citizenship and social class (Cambridge, Cambridge University Press).

Nicoll, K., Fejes, A., Olson, M., Dahlstedt, M. \& Biesta, G. J. J. (2013) Opening discourses of citizenship education: a theorization with Foucault. Journal of Education Policy, onlinefirst. DOI: 10.1080/02680939.2013.823519.

The National Swedish Agency for Education (2010) Skolor som politiska arenor: Medborgarkompetens och konflikthantering (Stockholm, Fritzes).

The National Swedish Agency for Education (2011) Läroplan för grundskolan, förskoleklassen och fritidshemmet 2011 (Stockholm, Fritzes).

Olson, M. (2009) Democratic Citizenship - A conditioned apprenticeship: A call for

Destabilisation of Democracy in education. Journal of Social Science Education 8(4), 75 80.www.jsse.org/2009/2009-4/olson-jsse-4-2009

Olson, M. (2012a) The European 'We': From Citizenship Policy to the Role of Education. Studies in Philosophy and Education 31(1), 77-89.

Olson, M. (2012b) Citizenship Education Without Citizenship? The Migrant in EU Policy on Participatory Citizenship - Toward the Margin Through 'Strangification'. In R. Hedke \& T. Zimenkova (Eds), Education for Civic and Political Participation: A Critical Approach (s. 155-170) (London: Routledge).

Olson, M. (2012c) What Counts as Young People's Civic Engagement in Times of Accountability? On the Importance of Maintaining Openness about Young People's Civic Engagement in Education. In M. Olson (Ed), Citizenship Education under Liberal Democracy. Utbildning \& Demokrati [Education \& Democracy] 21(1), 29-55.

Osler, A. \& Starkey, H. (2005) Changing citizenship democracy and inclusion in education (Maidenhead, England, Open University Press). Peters, M., Blee, H. \& Britton, A. (Eds) (2008) Global citizenship education: Philosophy, theory and pedagogy (Rotterdam, The Netherlands, Sense Publishers).

Phillips, K. R. (2002) Spaces of Invention: Dissention, freedom, and Thought in Foucault, Philosophy and Rhetoric, 35(4), 324-344.

Rabinow, P. \& Rose, N. (2003) Foucault Today. The Essential Foucault: Selections from the essential works of Foucault, 1954-1984 (New York, New Press).

Rose, N. (1999) The powers of freedom: Reframing political thought (Cambridge, Cambridge University Press).

Senellart, M. (2007) Course context, in M Foucault, Security, territory, population, Lectures at the College de France 1977-1978 (Basingstoke, PalgraveMacMillan).

Weller, S. (2007) Teenagers' Citizenship: Experience and education (Abingdon, Routledge).

Werbner, P. \& Yuval-Davis, N. (1999) Introduction: Women and the New Discourse of Citizenship, in: P. Werbner \& N. Yuval-Davis (Eds) Women, Citizenship and Difference (London and New York, Zed Books).

Westheimer, J. \& Kahne, J. (2004) What kind of citizen? The politics of educating for democracy, American Educational Research Journal, 41(2), 237-269.

Wilson, J. (2000) Volunteering, Annual Review of Sociology, 26, 215-240.

Öhrn, E., Beach, D. \& Lundahl, L. (2011) Young people's influence and democratic education. Ethnographic studies in upper secondary schools (London, Tufnell Press). 